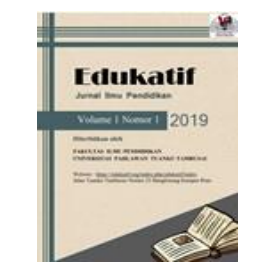

\title{
PENINGKATAN HASIL BELAJAR IPA DENGAN MENGGUNAKAN KLIPING PADA SISWA KELAS V SDN 006 SIALANG KUBANG
}

\author{
Masyithah $^{1}$ \\ Universitas Pahlawan Tuanku Tambusaii ${ }^{1}$ \\ e-mail : masyitah@gmail.com
}

\begin{abstract}
Abstrak
Latar belakang masalah dalam penelitian ini adalah siswa mudah lupa dengan materi yang diajarkan dan kurang memahami konsep dengan baik karena kebermaknaan materi bagi anak kurang diperhatikan. Dalam pendekatan RME ini menekankan akan pentingnya konteks nyata yang dikenal siswa dan proses konstruksi pengetahuan matematika oleh siswa sendiri sehingga konsep yang diterima siswa lebih bermakna. Penelitian ini dalam bentuk Penelitian Tindakan Kelas (PTK) dengan subjek penelitian siswa kelas VI SDIT Raudhaturrahmah Pekanbaru tahun ajaran 2013/2014. Tujuan dalam penelitian ini adalah untuk meningkatkan hasil belajar matematika siswa kelas VI SDIT Raudhaturrahmah Pekanbaru pada materi Operasi Hitung Pecahan. Data dalam penelitian ini adalah data kuantitatif yang diperoleh dari tes pengetahuan dan pemahaman siswa melalui ulangan harian. Hasil penelitian ini menunjukkan bahwa rata-rata persentase aktivitas guru pada siklus I adalah 85,22\% (Kategori: Amat Baik) dan pada siklus II adalah 93,18\% (Kategori: Amat Baik). Sedangkan persentase aktivitas belajar siswa pada siklus I adalah 70,5\% (Kategori: Cukup) dan meningkat menjadi 86,3\% (Kategori: Baik) pada siklus II. Rata-rata hasil belajar siswa pada skor dasar adalah 69,2 meningkat menjadi 92,1 pada siklus I dan meningkat lagi menjadi 95,9 pada siklus II. Sedangkan ketuntasan klasikal pada siklus I dan siklus II tercapai. Ini artinya bahwa penerapan pendekatan pendidikan matematika realistik dapat meningkatkan hasil belajar matematika siswa kelas VI SDIT Raudhaturrahmah Pekanbaru.
\end{abstract}

Kata Kunci: RME, hasil belajar matematika

@Edukasi: Jurnal Ilmu Pendidikan FIP UPTT 2019

\begin{tabular}{ll}
\hline$\triangle$ Corresponding author: & \\
Address : Pekanbaru & ISSN xxxx-xxxx (Media Cetak) \\
Email : masyithah@gmail.com & ISSN xxxx-xxxx(Media Online) \\
Phone :- &
\end{tabular}




\section{PENDAHULUAN}

IPA merupakan suatu ilmu yag membahas tentang gejala-gejala alam yang disusun secara sistematis berdasarkan pada hasil percobaan dan pengamatan yang dilakukan oleh manusia.

IPA tidak bisa hanya berbentuk sebuah konsep saja namun pembelajaran IPA secara praktek juga harus diterapkan. Secara tidak disadari kegiatan sehari-hari yang kita lakukan semuanya mengandung IPA. Jadi, bisa dikatakan bahwa IPA ada di sekitar kehidupan kita.

Pendidikan IPA seharusnya dilaksanakan dengan baik dalam proses pembelajaran di sekolah mengingat pentingnya pelajaran tersebut seperti yang telah di ungkapkan di atas. Pembelajaran IPA dikatakan berhasil apabila semua tujuan pembelajaran yang telah ditentukan dapat tercapai, yang terungkap dalam hasil belajar IPA.

Pembelajaran IPA SD menekankan pada pengalaman langsung dan kegiatan praktis untuk mengembangkan kompetensi siswa tentang alam sekitarnya secara ilmiah, siswa banyak berbuat, membaca, dan melihat sehingga memperoleh pemahaman yang lebih mendalam tentang konsepkonsep IPA. Maka hendaknya dapat memilih dan menggunakan alat peraga, strategi pembelajaran maupun media yang dapat melibatkan siswa lebih aktif belajar.

Berdasarkan pengalaman penulis selama mengajar pada kelas V SDN 006 SIALANG KUBANG dalam menyampaikan materi pelajaran guru lebih banyak menggunakan metode ceramah, jarang menggunakan alat peraga (media pembelajaran) dan keterbatasan sarana prasarana yang ada disekolah.

Dari gejala diatas menyebabkan hasil belajar siswa cenderung rendah dengan rata rata ulangan harian 58, dimana sekolah telah menetapkan kriteria ketuntasan minimal (KKM) 65. Rendahnya hasil belajar tersebut disebabkan siswa kurang aktif dalam belajar,jarang bertanya,kurang serius mengikuti pelajaran .

Dengan memperhatikan kondisi diatas perlu adanya perubahan dan perbaikan strategi pembelajaraan, seperti memperbaiki penggunaan alat peraga ( media pembelajaran ) sehingga siswa lebih pro aktif dalam belajar, lebih serius, dan lebih menarik. Sehingga hasil belajarnya meningkat. Salah satunya adalah dengan menggunakan kliping.
Kliping merupakan guntingan atau kumpulan artikel, berita, gambar, dari surat kabar, majalah, buku, untuk disimpan dan di dokumentasikan karena kliping merupakan salah satu media pengajaran dua dimensi. Menurut barung $\mathrm{k}$ kliping sebagai media pengajaran disekolah dalam rangka merealisasikan cara belajar siswa aktif ( CBSA ) dengan adanya penggunaan kliping suasana belajar akan lebih menarik, siswa banyak membaca, melihat , bertanya , dan berdiskusi dengan temannya sehingga proses belajar aktif.

Berdasarkan uraian diatas maka penulis tertarik melakukan penelitian dengan judul "Peningkatan Hasil Belajar IPA Dengan menggunakan kliping pada siswa kelas V SDN 006 SIALANG KUBANG tahun pelajaran 2013/2014

\section{METODE PENELITIAN}

Pelaksanaan penelitian tindakan kelas ini bersifat kolaboratif, maksudnya dalam penelitian nini peneliti bekerjasaama dengan rekan sejawat. Rekan sejawat bertindak sebagai observer, yang tugasnya untuk mengamati dan menilai segala aktivitas peneliti selama proses penelitian ini. Penelitian ini dilakukan oleh peneliti yang juga akan bertindak sebagai guru mata pelajaran IPA. Tujuan penelitian ini adalah untutk mengetahui kelemahan dalam proses pembelajaran dan mencari cara untuk mengatasi kelemahan tersebut dan meningkatkan mutu pembelajaran.

Wardani (2007:1.4) menyatakan bahwa penelitian tindakan kelas adalah penelitian yang dilakukan oleh guru di dalam kelasnya sendiri melalui refleksi diri dengan tujuan untuk memperbaiki kinerjanya sebagai guru, sehingga hasil belajar siswa meningkat. Sedangkan Arikunto (2006:60) menyatakan bahwa penelitian tindakan kelas (PTK) adalah penelitian yang dilakukan di kelas dengan tujuan memperbaiki atau meningkatkan mutu praktik pembelajaran. Tindakan kelas yang diberikan pada penelitian ini adalah penerapan Strategi Peta Konsep dalam rangka meningkatkan hasil belajar IPA siswa.

\section{HASIL PENELITIAN DAN PEMBAHASAN}

Penelitian tindakan kelas ini dilaksanakan pada klas V SD 006 Sialang Kubang, Kecamatan perhentian raja, semester satu tahun 
pelajaran 2013/2014 dengan materi pokok " Cara Mahluk hidup Menyesuaikan Diri Dengan lingkungannya ". Pelaksanaan tindakan ini dilakukan dalam 2 ( dua ) siklus yang terdiri dari 4 kali pertemuan dan dua kali ulangan harian. Setiap pertemuan terdiri dari 2 jam pelajaran yaitu 2 x 40 menit. Jumlah siswa 31 orang yang terdiri dari 15 orang laki-laki dan 16 orang perempuan.

Untuk mengetahui peninkatan hasil belajar IPA siswa pada siklus I dan Siklus II dengan menggunakan kliping pada siswa kelas V SDN 006 Sialang Kubang Tahun Pelajaran 2013-2014 dengan materi pokok "Cara Mahluk hidup Menyesuaikan diri dengan lingkungannya", dilakukan pengukuran terhadap hasil belajar siswa yang terdiri dari daya serap, ketuntasan individual dan ketuntasan klasikal.

hasil belajar siswa pada siklus pertama dari dua kali pertemuan mengalami peningkatan setelah menggunakan kliping dalam proses belajar mengajar.Pada pertemuan I rata-rata nilai post test 58,9 (kurang )Pertenakan pertemuan II 72,2 (Baik). Pada pertemuan I hasil belajar siswa masih di kategorikan kurang karena siswa belum terbiasa belajar menggunakan kliping, masih banyak bermain-main, selain itu siswa masih cenderung dengan kebiasaan belajar yang berpusat pada guru maka ketika siswa dihadapkan pada pembelajaran mandiri dengancara belajar kelompokdengan menggunakan kliping mempresentasikan hasil diskusi didepan ke;as belum efektif, sehingga pemahaman siswa tentang materi pelajaran masih kurang, maka hasil belajarnya juga rendah.

hasil belajar siswa dari nilai post test mengalami peningkatan pada setiap pertemuan.hal ini dapat dilihat dari pertemuan I rata-rata nilai post test yaitu 77,9 ( baik ) dan pertemuan I rata-rata nilai post test yaitu 85,8(amat baik). peningkatan ratarata daya serap siswa tersebut menunjukkan bahwa penggunaan kliping pada siswa kelas V SDN 006 Sialang Kubang sesuai dengan yang diharapkan. Siswa lebih mudah memahami konsep-konsep IPA ketika mereka menggunakan kliping, dalam belajar kelompok, berdiskusi, mengamati, membaca, keaktipan siswa dalam belajar meningkat karena kliping memuat artikel yang sigkat, padat yang disertai gambar-gambar, maka akan membuat siswa lebih lama tersimpan dalam ingatannya, sehingga hasil belajarnya meningkat lebih baik lagi.

Berdasarkan hasil ulangan harian siklus II nilai rata- rata 79,0 (baik) lebih baik dari pada siklus I dengan rata-rata 74,8 ( baik ). Meningkatnya nilai ulangan harian tidak terlepas dari peranan guru dan aktifitas siswa dalam proses belajar mengajar. Pada siklus II ini siswa lebih aktif dalam kegiatan belajar mengajar seperti melakukan pengamatan, membaca, mengerjakan LKS, bertanya dan menanggapi pertanyaan saat kerja kelompok hal ini menunjukkan ketertarikan siswa dengan menggunakan kliping dalam proses belajar mengajar, sehingga proses belajar mengajar dapat berjalan dengan baik.

pada ulagan harian siklus I terdapat 25 orang ( $80,6 \%$ ) siswa yang tuntas secara individu, 6 orang ( $19,4 \%$ ) siswa yang tidak tuntas. Secara klasikal kelas tersebut tidak tuntas ( $80,6 \%$ ). Tidak tuntas nya belajar siswa pada siklus I menunjukkan bahwa penerapan pembelajaran dengan menggunakan kliping belum maksimal, diduga siswa belum bisa dengan cepat beradaptasi dengan pembelajaran yang dianggap baru karena siswa belum adanya berbagi belajar dalam kelompok secaramaksimal, sehingga siswa kurang aktif bekerja sama dalam kelompoknya, misalnya melakukan pengamatan, mengerjakan LKS hanya siswa tertentu, kurang berdiskusi, banyak bermain, suka menggangu kawannya, maka pemahaman materi pelajaran juga kurang. Bagi siswa yang belum tuntas diberikan tugas untuk dikerjakan dirumah agar lebih memahami materi yang telah di ajarkan.

Menurut mustakim ( 1991 ), belajar tuntas adalah apabila semua siswa mau dan dapat belajar, serta menguasai tujuan pembelajaran yang diberikan pada waktu tertentu, sedangkan yang belum tuntas diberikan remedial.

Pada ulangan harian II siklus II terdapat 29 orang ( $93,5 \%$ )yang tuntas secara individu,dan siswwa yang belum tuntas 2 orang ( $6,5 \%$ ) secara klasikal kelas tersebut tuntas ( $935 \%$ ) dengan nilai rata-rata 79,0\% dengan kategori baik. Dari siklus I sampai dengan siklus II ketuntssan belajar siswa mengalami peningkatan baik ketuntasan klasikal, hal ini terbukti dengan meningkatnya siswa membaca, mengamati kliping lebih meingkatkan hasil belajar lagi.

Bagi siswa yang belum tuntas diberikan program perbaikan sampai sampai mencapai nilai 65. hal ini sesuai dengan pernyataan oleh anonimus ( 1994 ) bahwa suatu kelas sudah mencapai $85 \%$ daari jumlah siswa yang tuntas atau dengan nilai minimal 65 maka kelas tersebiut dikatakan tuntas. 
18 Peningkatan hasil belajar IPA dengan menggunakan kliping pada siswa kelas V SDN 006 Sialang KubangMasyithah

\section{KESIMPULAN}

Berdasarkan hasil penelitian dapat disimpulkan sebagai berikut Penggunaan kliping Pada materi pokok cara mahluk hidup menyesuaikan diri dengan lingkungannya pada kelas V SDN 006 Sialang Kubang dapat meningkatkan hasil belajar siswa dengan :

1. Daya serap siswa mengalami peningkatan pada siklus I rata - rata 74,8\% ( baik ) dan siklus II rata-rata nilai 79,0\% ( baik ).

2. Ketuntasan belajar siswa mengalami peningkatan, siklus pertama $86,6 \%$ belum tuntas ) dan siklus kedua adlah 93,5\% (tuntas).

3. Aktivitas belajar siswa mengalami peningkatan, siklus pertama $68,6 \%$ cukup ), siklus kedua 83,3\% ( amat baik ).

4. Aktivitas guru juga mengalami peningkatan, siklus pertama dengan ratarata $75 \%$, siklus kedua dengan rata-rata $100 \%$.

Diharapkan kepada guru SD khususnya guru IPA dapat menggunakan kliping sebagai media pengajaran karena dapat meningkatkan aktivitas siswa sehingga hasil belajarnya meningkat

\section{DAFTAR PUSTAKA} Abdurahman,2002.pendidikan bagi anak
berkesulitan belajar.Rineka cipta. Jakarta

Anonimus,1994.Petunjuk

Operasional Peningkatan Mutu Pendidikan dan Kebudayaa.Depdikbud.Jakarta.

Arsyad,Azhar.1997.Media Pengajaran.Grapindo Persada Jakarta.

Barung K.1990.kliping dan makalah Suatu Model Cara Belajar Siswa Aktip.PT.Gramedia Widiasarana Indonesia.Jakarta.

Depdikbud.1995.Kurikulum siswa dasar.Dirjen Pendas.Jakarta.

Djamarah.1996.strategi belajar mengajar.Rineka Cipta.Jakarta.

Djamarah,SB.2002.Prestasi Belajar dan Kompetisi Guru.Usaha Nasional. Surabaya.
Hamalik.1994.Media

Pendidikan.Tarsito.Bandung.

Hamalik.2001.Kurikulum dan Pembelajaran.Bumi Aksara.Jakarta.

Hotmaida,S.2000.Skripsi Peningkatan Proses Belajar Siswa dengan Penggunaan Kliping Pada Konsep Lingkungannya.Kelas I Cawu III SMUN 1 Kuantan Mudik.UNRI Pekanbaru.

Isjoni dan Kasmianto.2004.Implementasi Kurikulum Berbasis Kompetensi.Sutra Benta Perkasa.Pekanbaru.

Isjoni.2007.Cooperative

Learning.Mengembangkan Kemampuan Belajar Berkelompok.Alfabet.Bandung.

Japfa.2010.Flona.Kompas: Gramedia

Muchtar S.P dan Kasmuri.2004.Dunia IPA. Yudhistira:Jakarta.

Panut.2004.Dunia sains untuk kelas 6 sekolah dasar.yudhistira: Jakarta

Panut .2007.Dunia IPAsemester pertama kelas 6 $S D$. Yudhistira: Jakarta

Poerwadarminto.1989.Kamus Besar Bahasa Indonesia.Balai Pustaka.Jakarta.

Rositawaty, S dan aris muharam. 2008. Senang belajar ilmu pengetahuan alam untuk kelas $V \quad S D$. Pusat perbukuan : Jakarta

Slameto.1987.Belajar dan Faktor-Faktor Yang Mempengaruhinya.Rineka Cipta.Jakarta.

Sudjiono,A.2007.Pengantar Statistik Pendidikan .Rajawali.Jakarta 